\title{
CUTANEOUS ANTHRAX IN LIMA, PERU: RETROSPECTIVE ANALYSIS OF 71 CASES, INCLUDING FOUR WITH A MENINGOENCEPHALIC COMPLICATION
}

\author{
Ciro MAgUiÑA(1), Jorge FLORES DEL POZO(2), Angélica TERASHIMA(1), Eduardo GOTUZZO(1), Humberto GUERRA(1), José E. VIDAL(3), \\ Pedro LEGUA(1) \& Lely SOLARI(1)
}

\begin{abstract}
SUMMARY
Anthrax is a zoonosis produced by Bacillus anthracis, and as an human infection is endemic in several areas in the world, including Peru. More than $95 \%$ of the reported naturally acquired infections are cutaneous, and approximately 5\% of them can progress to meningoencephalitis. In this study we review the clinical and epidemiological characteristics of the patients with diagnosis of cutaneous anthrax evaluated between 1969 and 2002 at the Hospital Nacional Cayetano Heredia (HNCH) and the Instituto de Medicina Tropical Alexander von Humboldt in Lima, Peru. Seventy one patients were included [49/71 (69\%) of them men], with a mean age of 37 years. The diagnoses were classified as definitive (44\%) or probable (56\%). The most common occupation of the patients was agriculture (39\%). The source of infection was found in $63(88.7 \%)$ patients. All the patients had ulcerative lesions, with a central necrosis. Most of the patients (65\%) had several lesions, mainly located in the upper limbs (80\%). Four patients $(5.6 \%)$ developed meningoencephalitis, and three of them eventually died. In conclusion, considering its clinical and epidemiological characteristics, cutaneous anthrax must be included in the differential diagnosis of skin ulcers. A patient with clinical suspicion of the disease should receive effective treatment soon, in order to avoid neurological complications which carry a high fatality rate.
\end{abstract}

KEYWORDS: Anthrax; Bacillus anthracis; Cutaneous anthrax; Anthrax meningitis; Peru.

\section{INTRODUCTION}

Cutaneous anthrax is a disease known since ancient times. It was described as the "malignant plague" by Egyptians and Indians. Hippocrates called the disease "anthrax" (from the Greek term "anthrakos" which means coal, because of the black color of the skin lesion $)^{12}$. Anthrax is a zoonosis produced by Bacillus anthracis that affects mainly domestic and wild herbivorous animals. Humans are incidental hosts, and are infected through direct or indirect contact with animals or contaminated products ${ }^{32,33}$. Historically, cutaneous anthrax has received other denominations as "carbuncle", "malignant pustule", "malignant edema", and others.

B. anthracis is a Gram positive, non motile, spore-forming aerobic bacterium. The vegetative form is large and lacks flagella $(1-10 \mu \mathrm{m} x$ 1-1.5 $\mu \mathrm{m})$, and the spores are $1 \mu \mathrm{m}$ in diameter. Characteristically, chains of bacilli resemble bamboo shoots ${ }^{5,33,35}$. Virulence depends on sporulation $^{13}$ and the production of toxins ${ }^{3,11,25}$, both under genetic control $^{39}$.

The incidence of cutaneous anthrax is decreasing worldwide ${ }^{39}$. However, some endemic areas in Africa, Asia and America, have occasional outbreaks producing serious impact on the health and economy of the population ${ }^{10,14,20,31,33,39}$. In those areas misdiagnosis and sub notification are common problems which make real knowledge of the extent of the disease difficult. In contrast, in industrial countries the application of good control and monitorization measures have produced great reduction of the disease prevalence and its lethality in humans and cattle $^{38,39}$; anthrax is now considered a rare occupational disease ${ }^{33}$. In the USA, between 1944 and 2000, 224 cases of cutaneous anthrax were notified, but only five cases occurred between 1984 and 20007,8.

The initial clinical manifestation of anthrax depends on the way of entrance of the $B$. anthracis: cutaneous (if the skin had a previous lesion), inhalational or intestinal ${ }^{32,33,35}$. All presentations can have complications such as sepsis, meningoencephalitis, and a fatal outcome. The inhalational form has the highest lethality ${ }^{15,31,32}$.

Recently, the bioterrorist attacks in USA in 2001, demonstrated the possibility of the use of $B$. anthracis as a biological weapon. Since September 2001, there have been reported 22 confirmed or suspicious cases, 11 of them acquired by the inhalational and cutaneous form respectively ${ }^{9}$. The modern experience with inhalational anthrax is based on a considerable extent of the 1979 outbreak in Sverdlovsk, Russia, after the accidental escape and windborne spread of spores of $B$. anthracis from a biological weapons factory, that produced 68 deaths $s^{1,23}$

(1) Instituto de Medicina Tropical Alexander von Humboldt, Universidad Peruana Cayetano Heredia, Lima, Perú.

(2) Hospital Nacional Cayetano Heredia, Lima, Perú.

(3) Instituto de Infectologia Emílio Ribas, São Paulo, Brasil.

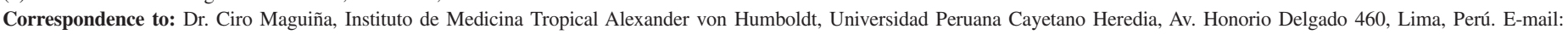
cirom@upch.edu.pe 


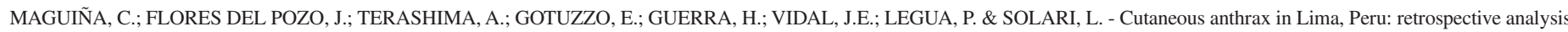
of 71 cases, including four with a meningoencephalic complication. Rev. Inst. Med. trop. S. Paulo, 47(1):25-30, 2005.

Several studies in Peru showed that cutaneous anthrax has been an important disease since more than one century at least $\mathrm{t}^{4,6,26,30}$. The last epidemiological summary of the Ministry of Health in Peru reported a national incidence of $0.46 \times 100,000$ inhabitants, from which, just about $30 \%$ of the cases had been properly confirmed ${ }^{26}$.

The purpose of the present study was to describe the clinical and epidemiological characteristics in Peruvian patients with cutaneous anthrax, including 4 cases with meningoencephalitis.

\section{MATERIALS AND METHODS}

Setting: The patients were seen at the Departamento de Enfermedades Transmisibles y Dermatológicas (DETD) of the Hospital Nacional Cayetano Heredia, and the Instituto Alexander von Humboldt of the Universidad Peruana Cayetano Heredia in Lima-Peru. Every patient with a diagnosis of cutaneous anthrax between 1967 and 2002 were included.

Design and methodology: This is a descriptive retrospective study. Medical records were examined, and information regarding clinical aspects, epidemiology and treatment were collected.

Definitions: A suspected case of cutaneous anthrax was defined as a patient with a cutaneous ulcer developing a black scab, in association with a history of direct or indirect contact with an herbivorous animal or its products (meat, organs, wool, bones). A definitive case was a patient with: 1) characteristic Gram positive bacilli in a lesion, or 2) identification of $B$. anthracis isolated from culture by specific methods.

The definition of meningoencephalitis due to anthrax required the inclusion of a suspected or definitive case of cutaneous anthrax and: 1) development of recent neurological abnormalities, 2) cytological and biochemical abnormalities in cerebrospinal fluid (CSF), with evidence of bacterial meningitis, and 3) Gram positive bacilli on a smear or presumably $B$. anthracis in culture of the CSF.

A secondary bacterial infection was defined by finding a purulent secretion in the cutaneous lesion.

The clinical evolution after the treatment was classified into three categories 1) favorable with rapid clinical improvement during the first three post-treatment days; 2) favorable with slow clinical improvement after the third day of treatment; and 3) unfavorable: clinical posttreatment worsening with fatal outcome.

Statistic analysis: descriptive epidemiology. Data of distribution were calculated using the EpiInfo 6.0.

\section{RESULTS}

Epidemiology: Seventy one cases were included, 31 (43.7\%) with a definitive diagnosis and $40(56.3 \%)$ with a suspected diagnosis. Forty nine patients $(69 \%)$ were men, and $22(31 \%)$ women. The mean age was $37 \pm 12.8$ years (range between eight and 67 years of age). Patients were dedicated mainly to agriculture $(28 / 71,39.4 \%)$, cattle raising $(17 / 71,23.9 \%)$ and meat handling $(10 / 71,14.1 \%)$. Most of the cases came from the Province of Lima $(63 / 71,88.7 \%)$, and in Lima, mainly from the District of Puente Piedra $(23 / 71,32.4 \%)$ and San Martín de Porras $(16 / 71,22.5 \%)$. The origin of the infection was found in $66 / 71$ $(93.0 \%)$ of the cases: $34(47.9 \%)$ described direct contact with meat and viscera during the sacrifice of a suspect animal, and in $26(36.6 \%)$ patients there was an antecedent of direct contact with meat. The disease was associated with a direct animal contact: beef cattle $(56 / 71,78.9 \%)$, goats $(10 / 71,14.1 \%)$ and swine $(5 / 71,7.0 \%)$. The period of incubation could be calculated in 45 cases, with a mean of $5.7 \pm 3.91$ days. Most of the cases, $42 / 68(61.8 \%)$, were reported between January and May.

Clinical Manifestations: The patients were admitted with duration of disease of $6.1 \pm 3.2$ days. The main complaints were the ulceration (100\%), local edema (60.6\%), itching (42.3\%), and local pain $(35.2 \%)$. The main systemic symptoms were fever $(69.0 \%)$, and malaise $(47.9 \%)$ (Table 1). Four patients (5.6\%) had meningismus, seizures, alterations of consciousness and coma. Two patients had anisocoria, and one patient had hemiparalysis. The most common signs were a cutaneous lesion with central necrosis $(100 \%)$, umbilicated ulcer $(94.4 \%)$, peripheral erythema $(73.2 \%)$, regional painful adenomegaly $(69.0 \%)$, and local edema $(60.6 \%)$ (Table 2).

Table 1

Symptoms presented by 71 patients with suspected and definitive diagnosis of cutaneous anthrax in Lima, Peru, 1967 to 2002

\begin{tabular}{lccc}
\hline Symptoms & $\begin{array}{c}\text { Suspected } \\
\text { diagnostic } \\
(\mathrm{n}=31)\end{array}$ & $\begin{array}{c}\text { Definitive } \\
\text { diagnostic } \\
(\mathrm{n}=40)\end{array}$ & $\begin{array}{c}\text { Total }(\%) \\
(\mathrm{n}=71)\end{array}$ \\
\hline Cutaneous ulcer & 31 & 40 & $71(100)$ \\
Fever & 22 & 27 & $49(69.0)$ \\
Local edema & 23 & 20 & $43(60.6)$ \\
Malaise & 16 & 18 & $34(47.9)$ \\
Local pain & 12 & 13 & $25(35.2)$ \\
Itching & 14 & 16 & $30(42.3)$ \\
Painful tumor & 6 & 10 & $16(22.5)$ \\
Functional limitation & 4 & 4 & $8(11.3)$ \\
\hline
\end{tabular}

Twenty-five (35.2\%) patients had a single lesion. The total number of different lesions was 187 . The body distribution of the lesions was mainly in the upper limbs $(79.7 \%)$ and the face $(9.1 \%)$. Lesions involved just one body area in $48(67.6 \%)$ patients, two areas in $22(31 \%)$, and three or more in only one $(1.5 \%)$ case.

There was secondary bacterial infection in $15(21.1 \%)$ of the cutaneous anthrax cases.

Laboratory Findings: Fifty eight blood cell counts were analyzed. Eighteen $(31 \%)$ showed an elevated leukocyte count (less than 20,000 cells $\left./ \mathrm{mm}^{3}\right)$, and $13(22.4 \%)$ had a left deviation.

Bacteriological studies were performed in 51 (71.8\%) patients. Direct smear of the ulcer was the most common test, and it showed Gram positive bacilli in $27(67.5 \%)$ of 40 patients. Culture of lesions found presumably B. anthracis in $8 / 25$ (32\%) of the patients. Additionally, among the patients with a purulent secretion, Gram positive cocci or bacilli were found in five cases, and cultures showed one case each of Staphylococcus epidermidis, Staphylococcus aureus, and Klebsiella 


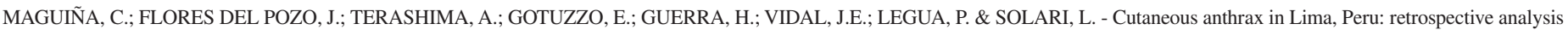
of 71 cases, including four with a meningoencephalic complication. Rev. Inst. Med. trop. S. Paulo, 47(1):25-30, 2005.

Table 2

Signs presented by 71 patients with suspected and definitive diagnosis of cutaneous anthrax in Lima, Peru, 1967 to 2002

\begin{tabular}{lccc}
\hline Signs & $\begin{array}{c}\text { Anthrax } \\
\text { diagnosis } \\
\text { suspected } \\
(\mathrm{n}=31)\end{array}$ & $\begin{array}{c}\text { Antrax } \\
\text { diagnosis } \\
\text { definitive } \\
(\mathrm{n}=40)\end{array}$ & $\begin{array}{c}\text { Total }(\%) \\
(\mathrm{n}=71)\end{array}$ \\
\hline Ulcer with central & 31 & 40 & $71(100)$ \\
necrosis & 38 & 29 & $67(94.4)$ \\
Umbilicated ulcer & 27 & 25 & $52(73.2)$ \\
Peripheral erythema & 27 & 22 & $49(69.0)$ \\
Regional adenopathy & 23 & 20 & $43(60.6)$ \\
Local edema & 15 & 14 & $29(40.8)$ \\
Local warm sensation & 13 & 16 & $29(40.8)$ \\
Perilesional infiltration & 12 & 7 & $19(26.8)$ \\
Regional edema & 8 & 7 & $15(21.1)$ \\
Purulent secretion & 6 & 3 & $9(12.7)$ \\
Sero-hematic secretion & 4 & 4 & $8(11.3)$ \\
"Crown of pearls" & 0 & 4 & $4(5.6)$ \\
Meningismus & 0 & 4 & $4(5.6)$ \\
Seizures & 0 & 4 & $4(5.6)$ \\
Loss of consciousness & & & \\
\hline
\end{tabular}

species. Blood cultures were taken in 17 patients, and in two $(11.7 \%)$ presumably B. anthracis was detected in sheep blood agar.

Cerebrospinal fluid (CSF) studies were performed in 4/71 (5.6\%) patients. The CSF was purulent in all cases with predominance of neutrophils (Table 3). Two patients had an open pressure reading of more than $20 \mathrm{~cm}$ of water. One patient had hemorrhagic meningitis, not caused by a traumatic lumbar puncture. Three cases showed Gram positive bacilli and presumably $B$. anthracis was isolated from one. In this case, sheep blood agar was used.

Treatment: Penicillin was the antibiotic more frequently used (48/ $71,67.6 \%)$; treatment lasted for a period of 5-10 days $(30 / 48,62.5 \%)$. The drug of choice for outpatients was procaine penicillin IM or PO. Hospitalized patients with no central nervous system (CNS) involvement received penicillin G 6-12 million IU/day until the remission of symptoms, then switching to procaine penicillin or penicillin V 1-2 millions IU/day. In the cases of CNS involvement, penicillin G 24 millions IU/day was used. Tetracycline was prescribed in seven $(9.9 \%)$ patients and erythromycin in one patient $(1.4 \%)$. Seven $(9.9 \%)$ patients received combined therapy, three cases with penicillin plus tetracycline and four cases with penicillin plus cloramphenicol. Eight $(11.3 \%)$ patients received no antibiotics or received them for less than 72 hours.

Clinical response: Sixty one $(85.9 \%)$ patients were hospitalized and $10(14.1 \%)$ were treated at the outpatient clinic. The clinical response could be evaluated in $66(93.0 \%)$ patients. One patient was transferred to another hospital and four did not return after discharge. The clinical response was favorable in $63(95.5 \%)$ cases and unfavorable in three $(4.5 \%)$. The majority of patients with favorable response (37, $58.7 \%$ ) had a rapid recovery; 35 (94.6\%) had cutaneous anthrax with no complications and two $(5.4 \%)$ had probable secondary bacterial infection, none had meningoencephalitis. Of the $26(41.3 \%)$ patients with slow favorable response, $12(46.2 \%)$ presented cutaneous anthrax without complications, $13(50 \%)$ had secondary bacterial infections and one $(3.8 \%)$ presented meningoencephalitis. The three patients with unfavorable clinical response had meningoencephalitis and died within 72 hours of admission, in spite of antibiotic treatment and life support measures. In other words, three of four patients with meningoencephalitis died. The only survived case remained in coma for 10 days. He recovered consciousness 15 days after admission, and had hemiparalysis as a sequel. This patient was discharged 30 days after admission without CNS involvement.

The fatality rate of this series was $4.2 \%(3 / 71)$.

\section{DISCUSSION}

This study represents the largest Peruvian series of cutaneous anthrax and is a contribution to the identification of some of its clinical and epidemiological characteristics.

Cutaneous anthrax is endemic in Peru. Cases are reported from the Departments of Lima, Lambayeque, Ica, Piura, Huancavelica, Ayacucho, Cajamarca, Ancash, La Libertad, and the province of Callao. Based on the information of the General Office of Epidemiology, Ministry of Health of Peru ${ }^{26}$, the number of cutaneous anthrax cases is decreasing from $300-350$ per year in the 80 's to less than 50 cases currently. The Lima Norte health area has the highest recorded incidence of animal and human anthrax in Peru.

The number of cases in the $\mathrm{HNCH}$ hospital has also decreased during the last years. The probable reasons are the progressive urbanization process, and the increased vaccination efforts on the part of the cattle raisers in the endemic rural portion of the extensive catchment area of the Hospital.

Table 3

Results of etiological and biochemical exams, Gram stain and culture of CSF from four patients with anthrax meningoencephalitis in Lima, Peru, 1967 to 2002

\begin{tabular}{|c|c|c|c|c|}
\hline Cases & Cytological exam & Biochemistry & Gram stain & Culture \\
\hline 1 & Abundant cells, predominantly $\mathrm{N}$ & NP & No bacteria & Negative \\
\hline 2 & Abundant cells, predominantly $\mathrm{N}$ & NP & Gram positive bacilli & Negative \\
\hline 3 & 32,000 cells $/ \mathrm{mm}^{3}, 96 \% \mathrm{~N}$ & G:15 mg\% P: 370 mg\% & Gram positive bacilli & Positive \\
\hline 4 & 17,250 cells $/ \mathrm{mm}^{3}, 90 \% \mathrm{~N}$ & $\mathrm{G}: 67 \mathrm{mg} \% \mathrm{P}: 2.400 \mathrm{mg} \%$ & Gram positive bacilli & Negative \\
\hline
\end{tabular}

N: neutrophils; G: glucose; P: proteins; NP: not performed. 


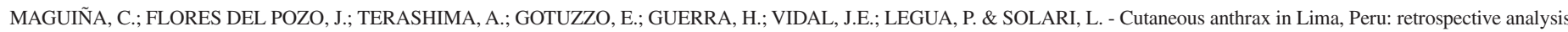
of 71 cases, including four with a meningoencephalic complication. Rev. Inst. Med. trop. S. Paulo, 47(1):25-30, 2005.

The most cases of this series were reported during the summer season (January-May). This relation between number of cases and ecologic conditions has been previously reported in Peru ${ }^{6,28}$ and other countries of Asia and Africa ${ }^{10,14,31,39}$.

Many reports associate outbreaks of human anthrax with cases in cattle $e^{4,6,14,28,31}$. In this study this association could also be observed. The manipulation of dead livestock is a risk factor for anthrax. This is conditioned by the absence of technical supervision and the illegal covert commercialization of meat, sometimes coming from sick animals.

Contrary to the African and Asiatic reports ${ }^{14,31,36}$, where the riskier occupation is cattle raising, the main occupation of Peruvian patients with cutaneous anthrax is agriculture ${ }^{4,6,21,28}$. In Peru, like in other Andean countries, many farmers also own a few domestic animals (cows, goats and pigs).

Anthrax presents diverse infection mechanisms. After entering the organism through skin lesions, inhalation or ingestion, the spores of the $B$. anthracis, are ingested by macrophages, which remain in the primary site of infection or move to the regional lymph nodes. The spores germinate in the macrophages and become vegetative bacteria, which multiply, destroy the macrophages and invade the lymphatic system, finally reaching the blood circulation ${ }^{3}$.

The main virulence factors of $B$. anthracis are coded in two plasmids $^{15,19,25}$. One of them codes for the polyglutamyl phagocytosisinhibiting capsule of the vegetative bacteria, and the other one carries the genes for toxin synthesis. The main toxins, denominated edema toxin and lethal toxin, are binary compounds ${ }^{33}$. Both have a common protein, component $\mathrm{B}$, which is necessary for entrance of the toxin into the guest's cells. Component A of edema toxin is edema factor, an adenylate-dependent calmodulin cyclase that is responsible for the often impressive local edema, neutrophil inhibition and stimulation of monocytes for production of tumoral necrosis factor and interleukin 6 . On the other hand, component $\mathrm{A}$ of the lethal toxin is a methaloprotease that inactivates intracellular signaling and stimulates the liberation of tumoral necrosis factor and interleukin $1 \beta$ by macrophages, contributing to the local toxic effects $s^{3,15,33,37}$. In the case of meningeal involvement, the anatomo-pathological events depend on these toxins, which cause hemorrhage and edema ${ }^{19}$. In the cases of inhalational anthrax, characterized by hemorrhagic throraxic lymphadenitis and hemorrhagic mediastinitis, the toxins cause severe inflammation and necrosis ${ }^{15}$.

The incubation period of cutaneous anthrax is usually from two to seven days, but reports on the beginning of clinical manifestations establish a period from nine hours up to eight weeks after the infecting $\operatorname{contact}^{35}$.

Anthrax presents three clinical forms: cutaneous, gastrointestinal and inhalational. Cutaneous anthrax is the most frequent (>95\% of the cases $)^{5,33,39}$ and gastrointestinal anthrax is very rare. Typically, the first manifestation of cutaneous anthrax is a painless erythema. This lesion changes to a papule lesion in 48 - 72 hours. In the following 2448 hours, multiple vesicles and a local red edema appear. Even without treatment, the lesions continue painless and have no purulent secretion ${ }^{35,38}$. In this series, one third of the patients manifested local pain, explained by secondary bacterial infection. One to three days after the first vesicles, the papules break and the ulcer with a black center appears, changing to a black eschar. At this time of the natural history, the patient presents fever, general malaise, toxemia, severe edema and painful regional lymphadenitis ${ }^{18,20,35}$. A few days after the formation of the eschar, a slow process of cure begins, which culminates in approximately six weeks after onset ${ }^{39}$. Around $80 \%$ of cases cure spontaneously. Local complications like secondary bacterial infections and severe edema are common, especially if the lesion is located in the thorax, neck or face ${ }^{18}$. Systemic complications are serious, and they include sepsis, meningoencephalitis, and death ${ }^{5,15,19}$.

Strict definitive diagnosis of cutaneous anthrax requires the isolation of $B$. anthracis from patient lesions or blood. Initial diagnosis depends on microscopic examination of smears from the base of the ulcer ${ }^{4,15,32,33}$, which is simple and inexpensive ${ }^{27}$. When there is high bacterial load, as in progressive inhalational anthrax, the micro-organisms may be visible directly on a Gram stained thin blood film ${ }^{16}$. In this situation, blood cultures are mandatory, and show growth in 6-24 hours ${ }^{32}$. However, cultures can be negative if the patients have received one or two doses of antibiotics ${ }^{16}$. The possibility of finding Bacillus species or $B$. cereus in cultures requires that suspect $B$. anthracis isolates be characterized fully ${ }^{16}$. In our study, despite clinical and epidemiological features, and result of cultures had showed that the lesions were probably caused by $B$. anthracis, the strains were not maintained to be identified with specific tests (for example, gamma-bacteriophage) in order to confirm that they were B. anthracis and no B. cereus. In special situations (for example, previous use of antibiotics, and negative smears and cultures), diagnosis of anthrax can require immunohistochemical exams or polymerase chain reaction ${ }^{16}$. The high cost of these tests makes them unavailable in developing countries.

The differential diagnosis of the cutaneous anthrax includes staphylococcal infection, cutaneous plague, tularemia, cutaneous diphtheria, typhus and other rickettsiosis, rat bite fever, gangrenous ecthyma, spider bite, syphilitic chancre and vasculitis ${ }^{27,37,39}$.

The neurological complications of cutaneous anthrax are uncommon, occurring in about $5 \%$ of the cases. Meningoencephalitis is characterized by a prodromic period of 1-6 days, fast onset of neurological involvement, and high fatality rate ${ }^{17,19,22,24}$. Generally, $75 \%$ of patients die in the first 24 hours of the onset of neurological symptoms $s^{2,4,19}$. Lethality of secondary meningoencephalitis after cutaneous anthrax cases is estimated to be around $95-100 \%{ }^{19,39}$.

The CSF from patients with anthrax meningoencephalitis is classically described as often hemorrhagic ${ }^{15,19}$. This characteristic was presented in only one of our patients. Anthrax should be considered in the differential diagnosis of patients with fever and acute neurological symptoms associated to necrotic ulcers on skin, and the discovery of Gram positive bacilli in CSF, with or without hemorrhage, is diagnostic ${ }^{24}$.

The differential diagnosis of anthrax meningoencephalitis includes the bacterial meningoencephalitis, especially that caused by Listeria monocytogenes, herpetic encephalitis, intracerebral hemorrhages, stroke, eclampsy and cerebral malaria ${ }^{19}$.

In developing countries, penicillin is the drug of choice for all clinical forms of anthrax. This is justified due to its low cost, easy 


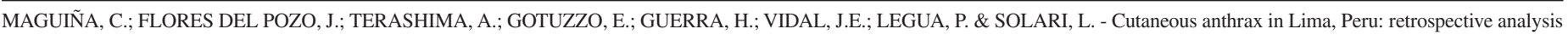
of 71 cases, including four with a meningoencephalic complication. Rev. Inst. Med. trop. S. Paulo, 47(1):25-30, 2005.

administration, availability and high susceptibility of the bacilli ${ }^{4,27,39}$. In the case of cutaneous anthrax, penicillin $\mathrm{V}$ or procaine penicillin, which sterilize the lesions in less than 72 hours in most cases, are preferred. The duration of treatment varies from three to 10 days according to clinical response ${ }^{32,39}$. Alternative drugs are the aminoglycosides, macrolides, quinolones, tetracyclines and cloramphenicol ${ }^{27,35}$. Early treatment diminishes the mortality and limits the size of the lesion but has little effect on the time of healing ${ }^{35}$. In the cases of meningoencephalitis penicillin $\mathrm{G}^{2,39}$ is recommended, in doses of two million UI every two hours, during a minimum of 14 days ${ }^{17,29,34}$.

The bioterrorist attacks during 2001 modified the therapeutic recommendations of anthrax in the United States ${ }^{16}$. Inducible beta lactamases were discovered in some $B$. anthracis strains, and the possible production of resistant anthrax through bioengineering, discouraged the use of ampicillin or penicillin as initial treatment during the terrorist $\operatorname{attack}^{9,19}$. In the case of cutaneous anthrax, fluoroquinolones or doxiciclin were preferred. Parenteral treatment is necessary in the case of systemic symptoms, extensive edema, head and neck involvement, and if the patient has less than two years old ${ }^{35}$. The duration of prophylactic treatment recommended was at least 60 days, due to the chance of inhalation of spores of B. anthracis ${ }^{35}$. In the cases of inhalational anthrax, in spite of not having enough information, the combined use of two or three antibiotics was advised. Among the antibiotics with appropriate effectiveness were quinolones, rifampin, tetracyclin, vancomycin, imipenem, meropenem, chloramphenicol, clyndamicin and aminoglicosides ${ }^{16}$. Additionally, the third generation cephalosporins, trimetroprim - sulfametoxazol and aztreonam should not be used, since $B$. anthracis has a natural resistance to these antimicrobials ${ }^{33}$. In the case of meningoencephalitis, combined antibiotic treatment is recommended, as for example ciprofloxacin or doxyciclin, associated to vancomycin and rifampin. Some physicians prefer ciprofloxacin over doxyciclin, and associate it with chloramphenicol or rifampin ${ }^{15,19}$.

The clinical response to the treatment of cutaneous anthrax is generally favorable and quick in uncomplicated patients. In patients with local complications, the response is also favorable, but usually slow. The mortality rate of cutaneous anthrax in the pre-antibiotic era was of $5-20 \%{ }^{6,28,32}$. After the introduction of penicillin, this percentage decreased to values smaller than $1 \%{ }^{32,39}$.

We conclude that cutaneous anthrax should be considered in the differential diagnosis of cutaneous ulcers, based on available clinical and epidemiological data. Early treatment reduces the chance of systemic complications, which have exceedingly high mortality rates. Finally, we consider it necessary to implement effective sanitary measures, such as animal vaccination, appropriate control of herbivores, their meat and their by-products, with the goal of further reducing the incidence of this illness.

\section{RESUMEN}

\section{Ántrax cutáneo en Lima, Perú: análisis retrospectivo de 71 casos, incluyendo cuatro con complicación meningoencefálica}

El ántrax es una zoonosis producida por el Bacillus anthracis y la infección humana es endémica en diversas partes del mundo, incluyendo el Perú. Más del $95 \%$ de las infecciones adquiridas naturalmente son cutáneas y aproximadamente 5\% de ellas pueden evolucionar para meningoencefalitis. En este estudio revisamos las características clínicas y epidemiológicas de los pacientes con diagnóstico de ántrax cutáneo evaluados entre 1969 y 2002 en el Hospital Nacional Cayetano Heredia (HNCH) y en el Instituto de Medicina Tropical Alexander von Humboldt, en Lima, Perú. Se incluyeron 71 pacientes [49/71 (69\%) del sexo masculino], con edad media de 37 años. Los diagnósticos fueron clasificados como definitivos (44\%) o probables (56\%). La ocupación más frecuente fue la agricultura (39\%). La fuente de infección fue identificada en $63(88.7 \%)$ pacientes. Todos presentaron lesiones ulcerativas con necrosis central. La mayoría de ellos (65\%) tuvieron lesiones múltiples, principalmente localizadas en miembros superiores (80\%). Cuatro pacientes $(5.6 \%)$ desarrollaron meningoencefalitis y tres de ellos fallecieron. En conclusión, considerando sus particulares características clínicas y epidemiológicas, el ántrax cutáneo debe ser siempre incluido en el diagnóstico diferencial de las lesiones cutáneas ulcerativas. Los pacientes con sospecha clínica de la enfermedad deben recibir tratamiento precoz con el objetivo de evitar complicaciones neurológicas, las cuales presentan elevados índices de fatalidad.

\section{REFERENCES}

1. ABRAMOVA, F.A.; GRINBERG, L.M.; YAMPOLSKAYA, O.V. \& WALKER, D.H. Pathology of inhalational anthrax in 42 cases from the Sverdlovsk outbreak in 1979. Proc. nat. Acad. Sci. (Wash.), 90: 2291-2294, 1993.

2. AL-ALlAF, G.A. - Anthrax meningitis. Trans. roy. Soc. trop. Med. Hyg., 72: 315, 1978.

3. ASCENZI, P.; VISCA, P.; IPPOLITO, G. et al. - Anthrax toxin: a tripartite lethal combination. F.E.B.S Lett., 531: 384-388, 2002

4. BARCELLI SOTO, C. - Tratamiento del carbunco por la penicilina. Lima, 1946. (Tesis de Bachiller en Medicina - Facultad de Medicina de la Universidad Nacional Mayor de San Marcos).

5. BARTLETT, J.G.; INGLESBY Jr, T.V. \& BORIO, L. - Management of anthrax. Clin. infect. Dis., 35: 851-858, 2002.

6. CARPENA, C. - Contribución al estudio del carbunco en el Perú. Lima, 1967. (Tesis de Bachiller en Medicina - Facultad de Medicina de la Universidad Nacional Mayor de San Marcos).

7. CENTERS FOR DISEASE CONTROL AND PREVENTION - Summary of notifiable diseases: 1945-1994. M.M.W.R., 43: 70-78, 1994.

8. CENTERS FOR DISEASE CONTROL AND PREVENTION - Summary of notifiable diseases: United States, 1999. M.M.W.R., 48: 82-89, 1999.

9. CENTERS FOR DISEASE CONTROL AND PREVENTION - Update: investigation of bioterrorism-related anthrax: Connecticut, 2001. M.M.W.R., 50: 1077-1079, 2001.

10. DAVIES, J.C. - A mayor epidemic of anthrax in Zimbabwe. Part II. Cent. Afr. J. Med., 29: $8-12,1983$.

11. EZZELL, J.W.; IVINS, B.E. \& LEPPLA, S.H. - Immunoelectrophoretic analysis, toxicity and kinetic of in vitro production of the protective antigen and lethal factor components of Bacillus anthracis toxin. Infect. Immun., 45: 761-767, 1984.

12. FREEDMAN, A.; AFONJA, O.; WU CHANG, M. et al. - Cutaneous anthrax associated with microangiopathic hemolytic anemia and coagulopathy in a 7-month-old infant. In: HENDERSON, D.A.; INGLESBY, T.M. \& O‘TOOLE, T., ed. Bioterrorism. Guidelines for medical and public health management. Chicago, AMA Press, 2002. p. 53-62. 


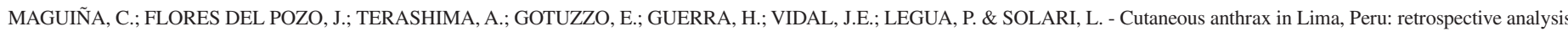
of 71 cases, including four with a meningoencephalic complication. Rev. Inst. Med. trop. S. Paulo, 47(1):25-30, 2005.

13. GREEN, B.D.; BATTISTI, L.; KOEHLER, T.M.; THORNE, C.B. \& IVINS, B.E. Demonstration of a capsule plasmid in Bacillus anthracis. Infect. Immun., 49: 291297, 1985.

14. HEYWORTH, B.; ROPP, M.E.; VOOS, U.G.; MEINEL, H.I. \& DARLOW, H.M. - Anthrax in the Gambia: an epidemiological study. Brit. med. J., 4: 79-82, 1975.

15. INGLESBY, T.V.; O'TOOLE, T.; HENDERSON, D.A. et al. - Anthrax as a biological weapon, 2002: update recommendations for management. J. Amer. med. Ass., 287: 2236-2252, 2002.

16. INGLESBY, T.V.; O’TOOLE, T.; HENDERSON, D.A. et al. - Anthrax as a biological weapon. Updated recommendations for management. In: HENDERSON, D.A.; INGLESBY, T.M. \& O'TOOLE, T., ed. Bioterrorism. Guidelines for medical and public health management. Chicago, AMA Press, 2002. p. 63-97.

17. KANUNGO, R.; KUMAR, A.; BHATTACHARYA, S. et al. - Problem of timely diagnosis in anthrax meningitis. J. Ass. Phycns India, 50: 913-915, 2002.

18. LAFORCE, F.M. - Anthrax. Clin. infect. Dis., 19: 1009-1014, 1994.

19. LANSKA, D.J. - Anthrax meningoencephalitis. Neurology, 59: 327-334, 2002.

20. LAVAL, E. \& SALAZAR. J. - Carbunco cutáneo: análisis clínico de 52 casos. Rev. med. Chile, 95: 774-777, 1967.

21. MAGUiÑA, C.; Flores DEL POZO, J.; TERASHiMA, A.; GOTUZZO, E. \& GUERRA, H. - Carbunco cutáneo en el Perú: revisión y experiencia. Folia derm. peru., 12: 21-28, 2001.

22. MARTÍN, C.O. \& ADAMS Jr., H.P. - Neurological aspects of biological and chemical terrorism: a review for neurologists. Arch. Neurol., 60: 21-25, 2003.

23. MESELSON, M.; GUILLEMIN, J.; HUGH-JONES, M. et al. - The Sverdlovsk anthrax outbreak of 1979. Science, 266: 1202-1208, 1994.

24. MEYER, M.A. - Neurologic complications of anthrax: a review of the literature. Arch. Neurol., 60: 483-488, 2003.

25. MIKESELL, P.; IVINS, B.E.; RISTROPH, J.D. \& DREIER, T.M. - Evidence for plasmidmediated toxin production in Bacillus anthracis. Infect. Immun., 39: 371-376, 1983.

26. OFICINA GENERAL DE EPIDEMIOLOGIA DEL MINISTERIO DE SALUD DEL PERU - Sistema Nacional de Vigilancia Epidemiológica. Anuario. Lima, Editorial del Ministerio de Salud del Perú, 2002. p. 23-27.
27. ÖNCUL, O.; ÖZSOY, M.F.; GUL, H.C. et al. - Cutaneous anthrax in Turkey: a review of 32 cases. Scand. J. infect. Dis., 34: 413-416, 2002.

28. PINEDA GANOZA, R. - Estudio epidemiológico y clínico del carbunco en el medio obrero. Lima, 1957. (Tesis de Bachiller en Medicina - Facultad de Medicina de la Universidad Nacional Mayor de San Marcos).

29. RANGEL, R.A. \& GONZALES, D.A. - Bacillus anthracis meningitis. Neurology, 25: 525-530, 1975.

30. SALINAS, D. - Ántrax en el Perú: la investigación pionera del siglo XIX. Bol. Soc. peru. Med. interna, 14: 44-49, 2001.

31. SAMAD, M.A. \& HUQUE, M.E. - Anthrax in man and cattle in Bangladesh. J. trop. Med. Hyg., 89: 43-45, 1986.

32. SPENCER, R.C. - Bacillus anthracis. J. clin. Path., 56: 182-187, 2003.

33. SWARTZ, M.N. - Recognition and management of anthrax: an update. New Engl. J. Med., 345: 1621-1626, 2001

34. TAHERNIA, A.C. \& HASHEMI, G. - Survival in anthrax meningitis. Pediatrics, 50: 329-333, 1972.

35. TUTRONE, W.D.; SCHEINFELD, N.S. \& WEINBERG, J.M. - Cutaneous anthrax: a concise review. Cutis, 69: 27-33, 2002.

36. VAN NESS, G.B. - Ecology of anthrax. Science, 172: 1303-1307, 1971.

37. WILLIAMS, R. - Bacillus anthracis and other spore forming bacilli. In: BRAUDE, A.I.; DAVIS, L.E. \& FIERER, J., ed. Infectious disease and medical microbiology. Philadelphia, W.B. Saunders, 1986. p. 270-278.

38. WORLD HEALTH ORGANIZATION - Anthrax: memorandum from a WHO meeting. Bull. Wld Hlth Org., 74: 465-470, 1997.

39. WORLD HEALTH ORGANIZATION - Guidelines for the surveillance and control of antrax in humans and animals. Avaliable at: http: // www.who.int/crs/resources/ publications/anthrax/whoemczdi986text.pdf. Accessed: October 2, 2003.

Received: 5 July 2004

Accepted: 30 November 2004 